\title{
Hepatitis A Virus Meningoencephalitis
}

\author{
Sedat Işıkay*1, Halil Kocamaz², Olcay Güngör', Serkan Kırık
}

\section{Sedat Işıkay ${ }^{* 1}$, Halil Kocamaz ${ }^{2}$, Olcay Güngör', Serkan Kırık ${ }^{1}$}

'Department of Pediatric Neurology, Kahramanmaraş Sütçü Imam University, Kahramanmaraş, Turkey

${ }^{2}$ Department of Pediatric Gastroenterology, Pamukkale University, Denizli, Turkey

\section{Correspondence}

\section{Dr. Sedat Isıkay,}

Division of Pediatric Neurology, Department of Pediatrics, Kahramanmaras Sütçü Imam University, 46000 ,

Kahramanmaras, Turkey

Ph.no:90(342)3606060, +905468481977; Fax: +90(342)3603928;

Email: dr.sedatisikay@mynet.com

\section{History}

- Submission Date: 20-11-2016;

- Review completed: 25-11-2016;

- Accepted Date: 25-11-2016.

DOI : 10.5530/ijmedph.2016.4.12

Article Available online

http://www.ijmedph.org/v6/i4

\section{Copyright}

(c) 2016 Phcog.Net. This is an openaccess article distributed under the terms of the Creative Commons Attribution 4.0 International license.
Sir,

A 10-year-old girl presented with a one-week history of abdominal pain, nausea and dark urine. On admission, she was icteric and drowsy with palpable liver $2 \mathrm{~cm}$ below the costal margin. The laboratory tests revealed elevated liver function tests with an aspartate aminotransferase level of $349 \mathrm{IU} / \mathrm{L}$ (8-40 IU/L), an alanine aminotransferase level of $1327 \mathrm{IU} / \mathrm{L}$ (7-56 IU/L), a gamma glutamyl transferase level of $370 \mathrm{U} / \mathrm{L}$ (9-24 U/L), an alkaline phosphatase level of $325 \mathrm{IU} / \mathrm{L}$ (30-100 IU/L), a total bilirubin of $3.3 \mathrm{mg} / \mathrm{dL}(0.2-1.2$ $\mathrm{mg} / \mathrm{dL})$ and direct bilirubin of $2.2 \mathrm{mg} / \mathrm{dL}(0.1-0.4$ $\mathrm{mg} / \mathrm{dL}$ ). The patient's plasma ammonia level was $67 \mathrm{mg} / \mathrm{dL}$ (15-45 mg/dL). Values of Prothrombin Time (14 seconds), activated Partial Thromboplastin Time (35 seconds) and International normalized ratio (1.12) were within normal ranges. In investigations, an immunoglobulin $\mathrm{M}(\mathrm{Ig} \mathrm{M})$ antibody against hepatitis A virus (HAV) was positive with negative serological markers for hepatitis $B$ and $C$ viruses. The Widal and Weil Felix tests were negative. She was afebrile. On the $2^{\text {nd }}$ day she had generalized tonicclonic convulsions for two times. She did not have a history of head trauma, drug intake or seizures. In physical examination there was not any flapping tremor and her ammonia level was determined as $50 \mathrm{mg} / \mathrm{dL}$ on the $2^{\text {nd }}$ day. An electroencephalogram revealed asynchronic irregular delta activity bilaterally together with sharp spike waves. Cerebrospinal fluid (CSF) analysis demonstrated mild lymphocytic pleocytosis (4 cells $/ \mathrm{mL}$ ), with mildly elevated proteins $(85 \mathrm{mg} / \mathrm{dL})$ and normal glucose $(74 \mathrm{mg} / \mathrm{dL})$ levels suggestive of aseptic meningitis. Evaluation under the dark-field microscope for leptospirosis was negative. She did not have a travel history and since Dengue fever or Tsutsugamushi disease are not reported in Turkey before, we did not investigate for those diseases. Magnetic resonance imaging (MRI) revealed small hyperintense areas in white matter (Fig 1). She did not have any chorea-athetotic movements reminding acute disseminated encephalomyelitis and the hyperintense areas in MRI were not large or as much as reported in acute disseminated encephalomyelitis. The symptoms improved with levetiracetam treatment for seizures and conservative management for HAV infection in 7 days. Follow-up brain MRI after one month revealed complete resolution. Though we did not determine the HAV IgM or RNA in CSF; since the convulsions started in the course of HAV infection with the findings of meningoencephalitis without any other causes and completely resolved with the treatment of this infection; these seizures were attributed to the meningoencephalitis of HAV infection.

Hepatitis A virus associated meningoencephalitis in childhood is an extremely rare condition with only few cases in literature. HAV belongs to the Picornaviridae family and other members of this family are well known to cause encephalitis; so this association is not astonishing. On the other hand, direct invasion of the central nervous system by the virus, accumulation of toxic metabolites and activation of immunologic mechanisms may be suggested to play a role in the neurological manifestations of the disease. ${ }^{1-3}$ Though HAV associated encephalitis and seizures are very rare; in cases with seizure and elevated liver function tests or jaundice; HAV should be kept in mind as an etiological agent.

\section{REFERENCES}

1. Yis U, Carman KB, Yılmaz-Çiftdogan D, Yıldırım C, Yis R, Akar E. Hepatitis A infection presenting with recurrent seizures and widespread cerebral white matter lesions. Turk J Pediatr 2013;55:118-20.

2. Cam S, Ertem D, Koroglu OA, Pehlivanoglu E. Hepatitis A virus infection presenting with seizures. Pediatr Infect Dis J 2005;24:652-3. http://dx.doi.org/10.1097/01.inf.00001 68754.24478.6d; PMid:15999014.

3. Davoudi S, Soudbakhsh A, Emadikouchak H, Nikbakht G, Modabbernia A. Meningoencephalitis associated with hepatitis $A$ infection: a case report and review of literature. Trop Doct 2010;40(3):176-7. http://dx.doi. org/10.1258/td.2010.090424; PMid:2055505.
Cite this article : Işıkay S, Kocamaz H, Güngör O, Kırık S. Hepatitis A Virus Meningoencephalitis. Int J Med. Public Health. 2016;6(4):209. 